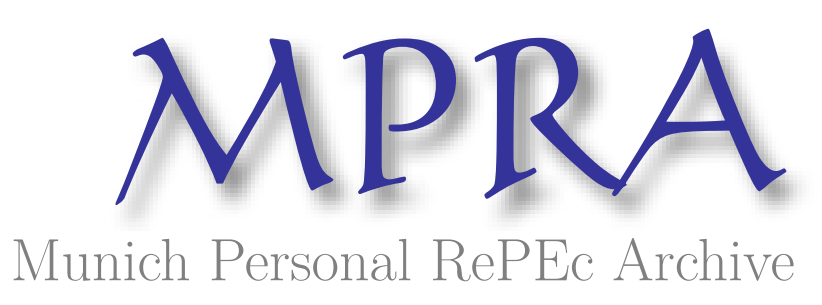

Impact of Interest Rates on Islamic and
Conventional Banks: The Case of Turkey

Etem Hakan, Ergeç and Bengül Gülümser, Arslan

January 2011

Online at https://mpra.ub.uni-muenchen.de/29848/

MPRA Paper No. 29848, posted 04 Apr 2011 06:17 UTC 


\title{
Impact of Interest Rates on Islamic and Conventional Banks: The Case of Turkey
}

\author{
Etem Hakan Ergeç ${ }^{\mathrm{a}^{*}}$ and Bengül Gülümser Arslan ${ }^{\mathrm{b}}$
}

\begin{abstract}
Identifying the impact of the interest rates upon Islamic banks is key to understand the contribution of such institutions to the financial stability, designing monetary policies and devising a proper risk management applicable to these institutions. This article analyzes and investigates the impact of interest rate shock upon the deposits and loans held by the conventional and Islamic banks with particular reference to the period between December 2005 and July 2009 based on Vector Error Correction (VEC) methodology. It is theoretically expected that the Islamic banks, relying on interest-free banking, shall not be affected by the interest rates; however, in concurrence with the previous studies, the article finds that the Islamic banks in Turkey are visibly influenced by interest rates.
\end{abstract}

JEL classification: G21; E52

Keywords: Interest-free banking, monetary policy

\section{Introduction}

Islamic banks ${ }^{1}$ are defined as financial institutions that rely on the principle of Profit and Loss Sharing (PLS) with the entrepreneurial partners in their relevant banking activities (Nienhaus, 1983, p. 31). From a unique perspective, these institutions may be properly identified as alternatives to modern conventional banks (Van Schaik, 2001, p. 46). Islamic banks basically operate in reliance on PLS paradigm. The term Islamic PLS refers to a relationship between the borrower, lender and intermediary built upon financial trust and partnership (Yudistira, 2003, p. 2).

Estimates underline that there are currently over 300 institutions in 80 countries carrying out interest-free banking. The interest-free funds have significantly increased from only 150 billion dollars in the 1990s to over 1 trillion dollars by the end of 2008. This refers to a $23 \%$ annual growth; analysts also estimate that the amount of these funds will reach to 1.5 trillion dollars by 2013 (Participation Banks, 2009 , p. 29). It should be noted that these financial instruments are popular not only in predominantly Muslim countries but also in non-Muslim nations (i.e., HSBC, Standard Chartered Bank, Deutsche Bank, Citibank, etc.). A growing number of

\footnotetext{
${ }^{a}$ Department of Economics, Eskisehir Osmangazi University, Turkey

*Corresponding author. E-mail: ehergec@ogu.edu.tr

${ }^{\mathrm{b}}$ Department of Economics, Anadolu University, Turkey

${ }^{1}$ In this article, Islamic bank refers to "interest-free deposit bank" and conventional bank to "interestbased deposit bank."
} 
banking institutions in these countries now offer interest-free banking services to their customers including non-Muslims who have a keen interest PLS financial instruments (Awan, 2009, p. 1).

The first Islamic banks in Turkey were introduced under the name of Special Finance Houses (SFH) in 1985 upon completion of the legal foundation during the period between 1983 and 1985. Under new regulations adopted in 2005, the titles of these institutions were converted to participation bank and they were further subjected to the same regulations as conventional banks in 2006. While the number of these interest-free banking institutions was 7 at the beginning, there are currently only four participation banks.

Table 1. Selected indicators of participation and conventional banks in Turkey

\begin{tabular}{|l|ccccc|ccccc|}
\hline \multirow{2}{*}{$(\%)$} & \multicolumn{4}{c|}{ Participation Banks } & \multicolumn{4}{c|}{ Conventional Banks } \\
\cline { 2 - 10 } & $\mathbf{2 0 0 5}$ & $\mathbf{2 0 0 6}$ & $\mathbf{2 0 0 7}$ & $\mathbf{2 0 0 8}$ & $\mathbf{2 0 0 9}$ & $\mathbf{2 0 0 5}$ & $\mathbf{2 0 0 6}$ & $\mathbf{2 0 0 7}$ & $\mathbf{2 0 0 8}$ & $\mathbf{2 0 0 9}$ \\
\hline \hline Share in Total Assets & 2.69 & 3.04 & 3.67 & 3.90 & 4.50 & 97.31 & 96.96 & 96.33 & 96.10 & 95.50 \\
Share in Total Loans & 5.05 & 5.11 & 5.59 & 5.72 & 6.82 & 94.95 & 94.89 & 94.41 & 94.28 & 93.18 \\
Share in Total Private Loans & 5.14 & 5.20 & 5.68 & 5.86 & 7.04 & 94.86 & 94.80 & 94.32 & 94.14 & 92.96 \\
Share in Total Deposits & 3.52 & 3.83 & 4.34 & 4.41 & 5.46 & 96.48 & 96.17 & 95.66 & 95.59 & 94.54 \\
Share in Total FX Deposits & 4.70 & 5.19 & 5.97 & 5.39 & 6.05 & 95.30 & 94.80 & 94.03 & 94.61 & 93.95 \\
\hline \hline
\end{tabular}

Source: Arslan and Ergeç (2010, p. 159)

Table 1 provides some ratios on participation banks and conventional banks for the purpose of having a basic idea on the development of participation banks after 2005 . In this 5-year period, it is evident that the in-system weight of the participation banks operating in Turkey has visibly increased. These banks seek to increase their insystem total stakes up to $10 \%$ in the near future (Participation Banks 2009, p. 5). The size of assets of participation banks refers to a greater development than that of conventional banks after 2006. Considering the higher rate of development displayed by the interest-free finance markets in international markets, it is plausible to anticipate that the participation banks in Turkey will continue to increase their insystem weight in the future as well (Arslan and Ergeç, 2010).

Identifying how the Islamic banks, with a possible increase of their in-system weight, will be influenced by the fluctuations in interest rates matters in Turkey employing a dual-banking system for a number of reasons. Analyzing the impact of the changes in the interest rates upon Islamic banks is important for financial stability, monetary policies and risk management in banking. 
The involvement of Islamic banks in interest-free banking refers to a possibility for positive contribution to financial stability. The chief reasons for such a positive contribution include their protection against fluctuations in interest rates, small possibility of bankruptcy, unlikeness to integrate with international markets and obligation to stay away from speculations.

The primary reason that Islamic banking may become more stable compared to conventional banks is that they are not affected by the fluctuations on interest rates (Kassim et al., 2009). This means that Islamic banks should be more stable than the conventional banks. Where Islamic banking is not influenced by interest rates, it is highly likely that demand for money will become more stable in the economy. Stability in demand for money holds some positive effects in terms of efficiency in monetary policies and the financial stability in the system. Kia and Darrat (2007) refer to two major reasons for positive impact of interest-free banking system upon stability in the demand for money. These are speculation from a demand perspective and revaluation of balance sheet items from a banking perspective. Of factors determining demand for money, interest rates appear to be the most visible component that is subject to speculation. Because they stay away from interest rates, Islamic banking transactions may introduce a more stable function of demand for money in the presence of Islamic funds as replacement. In this case, absence of interest rates may "mitigate structural breaks in the underlying demand relationships resulting from exogenous shocks" (Kia and Darrat, 2007, p. 105). It should also be noted that in case of changes in the interest rates, the banks revalue their assets before liabilities. The loan interest rates respond to a change in the interest rate much earlier than the savings interest rates. In this case, the revaluation of balance sheet entries, a key component of motive for profit maximization, makes the impact of the fluctuation in the interest rates much stronger. However, in the Islamic banking system, there is no need for revaluation of balance sheet entries because there is no risk of interest rate involved. For these two primary reasons, it is anticipated that the demand for money becomes more instable in conventional banking system. ${ }^{2}$

\footnotetext{
${ }^{2}$ In the literature on Islamic banking, Darrat (1988) reviews the Tunisian system whereas Zuberi (1992) focuses on Pakistan. Darrat (2002) investigates the Islamic banking system in Iran and Pakistan while Kia (2002) evaluates the place of Islamic banking in Iranian national economy. Kia and Darrat (2007) also studies how the system works in Iran. All these studies present empirical findings suggesting that demand for money is more stable in Islamic banking.
} 
Operating through the PLS paradigm, the Islamic banks have the opportunity of reflecting their financial losses to the customers. This may mean that they are able to balance exogenous shocks more effectively (Errico and Farahbaksh, 1998, p. 11; Khan and Mirakhor, 1990, p. 356-357). Zuberi (1992) likens the PLS, based on sharing the risk and profit in Islamic banking, to the capital venture. Because they are able to reflect the losses to their customers, the Islamic banks are less likely to go bankrupt in times of crisis compared to the conventional banks. This means that Islamic banks are actually more stable than the conventional banks (Al-Jarhi, 2009, p. 14). In addition, because they are less integrated with the international financial markets, the Islamic banks are not significantly influenced by short term financial flows. This is another factor supporting the argument that they are more stable than the conventional banks (Zarqa, 1983, p. 184-185). To this end, it should also be noted that the operating principles of the Islamic banks ${ }^{3}$ require them to stay away from speculations (Al-Jarhi, 2009, p. 14).

Analyzing how interest rates influence Islamic banking in national economies with a dual banking system is of great salience for the success of monetary policies and regulation of the financial system. ${ }^{4}$ This becomes even more imminent in economies where the share of the interest-free banking system visibly raises as interest rates occupy a crucial place within the set of target variables of monetary policies. Therefore, the ability to attain the monetary policy goals calls for a better understanding of the impact of this tool upon interest-free banking.

Where Islamic banks are not influenced by interest rates and therefore become more stable than the conventional banks, a monetary system relying on interest-free assets is proposed to have lesser element of uncertainty, thereby becoming more predictable and reliable by virtue of having links to monetary policy objectives. The interestfree monetary instruments are considered to be valid and effective and useful; they

\footnotetext{
${ }^{3}$ Islamic banks are based on prescriptions in Shariah law. The basic principle in the Shariah (the Islamic Law) is that exploitative contracts based on Riba (interest or usury) or unfair contracts that involve risk or speculation (Gharar) are unenforceable (Zaher and Hassan, 2001)

${ }^{4}$ Chang and Liu (2009), in their study where the relationship between the return of deposit in Malaysian economy are analyzed, show that in practice, Islamic banking is not significantly different from conventional banking. For this reason, they conclude that Islamic banks should be subjected to the rules applying to the conventional banks.
} 
may be even regarded as tools better than the interest-based monetary instruments in terms of the implementation of monetary policies (Kassim et al., 2009). ${ }^{5}$

Haron and Shanmugam (1997) evaluate a number of countries practicing Islamic banking including Turkey. They further elaborated on various concepts of Islamic financial products along with the monetary policy. This research reviews the murabahah tools as important items of monetary policy to replace the current interest-based discount rate.

Risk management is another primary factor requiring attention in the impact of the interest rates upon Islamic banking. In economies employing dual banking system in particular, whether the Islamic banks are affected by the interest rates bears importance for risk management. The view that the Islamic banks are not influenced by interest rates when they actually $\mathrm{do}^{6}$ is a huge flaw that needs to be taken into consideration in terms of risk management (Kassim et al., 2009). Whether Islamic banks are subjected to interest risk is significant not only because of the success in the risk management at these institutions but also because of the success in the risk management of conventional banks that constitute the other side of the whole banking system.

A number of empirical studies focusing on dual banking system underline that interest rate strongly affects Islamic banking system. The probable reasons cited in these studies for such an impact include influence by interest rates upon deposits, the encounter with negative fund gap and deprivation from arbitrage opportunities.

It was found in many empirical researches that the change in interest rates may affect not only the deposits in conventional banks but also the deposits reserved in Islamic banks. $^{7}$ The reasons for the individuals to prefer Islamic banks as institutions

\footnotetext{
${ }^{5}$ Chapra (1996), Uzair (1978), Khan and Mirakhor (1989) and Zangeneh and Salam (1993) are purely theoretical accounts reviewing the role of the monetary policies and central bank in economies with an interest-free banking system. Said and Ismail (2008), Kassim at al. (2009) and Sukmana and Kassim (2010) present empirical findings on how monetary policies influence Islamic banking and economy in economies with a dual banking system.

${ }^{6}$ Bacha (2004) and How et al. (2005) are empirical works concluding that the Islamic banks operating in a dual banking system face an interest rate risk.

${ }^{7}$ Examples for empirical studies referring to a positive relationship between the volume and size of the deposits and the return of Islamic deposits in Islamic banks and a negative correlation between the size of Islamic deposits and the conventional interest rate include Kassim, et al. (2009), Haron and Ahmad (2000), Kasri and Kassim (2009), Sukmana and Kassim (2010), Zaionol and Kassim (2010).
} 
collecting deposits include religious and economic factors which a growing number of studies pay attention to. ${ }^{8}$ Most of these studies recall that economic factors are as important as religious factors for the depositors. If interest rates are influential over Islamic banking deposits, this means that the positive impact of interest-free banking upon financial stability is restricted.

Islamic banking units are influenced by interest rates because they are subjected to negative fund gap. Rosly (1999) demonstrates in a study where the influence of change in the interest rates in Malaysia upon one Islamic bank and 5 conventional banks is evaluated that increase in interest rates subjects the Islamic banks to negative fund gap, reducing their rate of profitability. Because they suffer from overdependency on fixed rate asset financing (such as al-bay'bithaman ajil and Murabahah), funds gap will always be negative where all Islamic liabilities are interest-sensitive. Rosly (1999) further concludes that Bank Islam Malaysia appears to be the only bank suffering from a decline in profitability while conventional banks increase interest margins, suggesting that Islamic banks are negatively affected by changing in the interest rates. ${ }^{9}$

In economies with dual banking system, the conventional banks enjoy the flexibility to engage in both regular banking activities and interest-free banking as well whereas the Islamic banks are unable to benefit from arbitrage advantages because of their limited competence to make transactions in interest-free financial markets only (Kaleem and Isa, 2006). However, the Islamic banks are more sensitive to the changes in interest rates compared to the conventional banks because they are operating in shallow financial markets (Kassim et al., 2009). Sukmana and Kassim (2010), in their study focusing on Malaysian economy, seek to identify the role of the Islamic banks in the monetary transmission mechanism. They find that Islamic deposits give a negative response to a shock in interest rates. This negative

\footnotetext{
${ }^{8}$ Erol and Bodur (1989) and Gerrard and Cunningham (1997) find that economic factors are as important as religious reasons in Jordanian and Singaporean economies respectively. Metawa and Almossawi (1998) and Naser et al. (1999) conclude that religiosity is the key factor in preferring Islamic banks in Bahrain and Jordan respectively. Okumuş (2005) finds that religious considerations make the top of the list for the customers to prefer the Islamic banks in Turkey in 2004. Haron et al. (1994) stress that the factors affecting preference in favor of Islamic banks or conventional banks are no different in Malaysia, suggesting that religiosity should not be cited as a major factor for the customers to pick Islamic banks.

${ }^{9}$ In case of increase in interest rates, the demand for Islamic loans also increases because of relatively reduced cost compared to the conventional bank loans. Islamic banks have to maximize the profitability rates in the deposits in order to meet this demand.
} 
relationship refers to a displaced commercial risk for the Islamic banks. An increase in the interest rates take the deposit holders from Islamic banks to the conventional banks because of the advantages involved in keeping money in the latter. This study finds out that an increase in interest rates reduces the size of the Islamic deposits, also causing shrinkage in the amount of Islamic funds and finances. It also concludes that Islamic banks do not have a flexible funding mechanism because of its reliance on deposits. Because of the volatility in the deposits, the study stresses that Islamic monetary markets need to be improved for the Islamic banks.

It is now evident that in economies with a dual banking system, there are factors suggesting that the interest rates influence Islamic banking. This is particularly important for proper identification of the contribution of interest-free banking to financial stability, the successful design of monetary policies and risk management for the banking system. This further bears some relevance depending on the share and weigh of Islamic banking in a dual banking system. This study analyzes the influence of interest rates on conventional banks and Islamic banks in Turkish economy. It seeks to identify how a change in interest rates affects the loans and deposits held in Islamic and conventional banks from a comparative perspective.

\section{Econometric Methodology and Data}

The impact of the interest rate shock upon the loans and deposits of the participation and conventional banks in Turkey is analyzed by Vector Autoregression (VAR). Sims (1980) upholds that if there is simultaneity among a number of variables, no distinction should be made between these variables as endogenous or exogenous and all variables should be considered as endogenous. VAR is a simple method where the econometrician has no concern as to which variable is endogenous and which is not. All variables in the model are endogenous. Each equation can be estimated with the OLS method separately. Forecasts obtained from VAR models are in most cases better than those obtained from the far more complex simultaneous equation models (Asteriou and Hall, 2007, p. 279-280).

In order to investigate the relationships between the variables employed in the study based on Impulse-Response Function (IRF) and Variance Decomposition (VDC) analyses within the VAR method, the status of stationary in respect to the variables included in the model should be identified via unit root tests. If the variables are 
identified as stationary in the level, standard VAR analysis is applicable with the level data; however, if the variables are found out to be I(1), we search for a cointegrating relationship between these variables. If the variables are I(1) and are not cointegrated, a VAR analysis is run with the first differences (Enders, 2004, p. 287).

Finally, for nonstationary variables and a cointegrated relationship, we estimate a VEC model. A VEC model is a special form of the cointegrated VAR I(1) variables (Griffiths et al., 2008).

In this study, we estimate the four VARs in levels using monthly data between 2005:12 and 2010:07. All variables are expressed in logarithms and computed in real terms except the overnight rate. The consumer price index and the industrial production index variables are seasonally adjusted by CensusX12 method. All data is obtained from the Electronic Data Delivery System (EDDS) of the Central Bank of the Republic of Turkey (CBRT). Table 2 shows the data used for the analysis.

Table 2. List of variables

\begin{tabular}{cc}
\hline \hline ON & Interbank overnight interest rates \\
$P$ & Consumer price index \\
$I P I$ & Industrial production index \\
$C L$ & Conventional banks total loans \\
$C D$ & Conventional banks total deposits \\
$I L$ & Islamic banks total loans \\
$I D$ & Islamic banks total deposits \\
$R E R$ & Real exchange rate \\
\hline \hline
\end{tabular}

The four VAR models drafted to compare the impact of the interest rate shock over the balance sheet items of Islamic and conventional banks are made of five endogenous variables ${ }^{10}$. The order of the variables in the VAR system bears importance for the impulse-response and variance decomposition analyses. The order of the variables is as follows for this study ${ }^{11}$ :

\section{VAR1: ON CD P IPI RER \\ VAR2: ON CL P IPI RER \\ VAR3: ON ID P IPI RER \\ VAR4: ON IL P IPI RER}

\footnotetext{
${ }^{10}$ Because Turkey is open economy, the real exchange rate is included in the model.

${ }^{11}$ To check the sensivity of the results to VAR order, we repeated our analysis with interest rates in the fifth and balance sheet items in the fourth place in the VAR; the results were similar.
} 


\section{Empirical Result}

\section{Unit Root Test results}

The order of integration of the variables is tested using the Augmented Dickey-Fuller (ADF) and Phillips-Peron (PP) procedure. For ADF test, the lags are chosen automatically on the basis of Schwartz Information Criterion (SIC) (with maximum lag 10); at the PP test, the lag length for Barlett Kernel is picked in line with the Newey-West correction. Table 3 represents the results of the unit root tests for each variable. The $\mathrm{ADF}$ and $\mathrm{PP}$ tests indicate nonstationary in levels but stationary in first differences for all variables. Therefore, all variables appear to be integrated of order 1.

Table 3. Result of the Unit Root Tests

\begin{tabular}{|c|c|c|c|c|c|c|c|c|}
\hline \multirow{3}{*}{ Değişkenler } & \multicolumn{4}{|c|}{$\mathbf{P P}$} & \multicolumn{4}{|c|}{ ADF } \\
\hline & \multicolumn{2}{|c|}{ Level } & \multicolumn{2}{|c|}{ First Difference } & \multicolumn{2}{|c|}{ Level } & \multicolumn{2}{|c|}{ First Difference } \\
\hline & $\mathbf{C}^{\mathbf{a}}$ & $\mathrm{C}+\mathrm{T}^{\mathrm{b}}$ & $\mathbf{C}^{\mathbf{a}}$ & $\mathbf{C}+\mathbf{T}^{\mathbf{b}}$ & $\mathbf{C}^{\mathbf{a}}$ & $\mathbf{C}+\mathbf{T}^{\mathbf{b}}$ & $\mathbf{C}^{\mathbf{a}}$ & $\mathbf{C}+\mathbf{T}^{\mathbf{b}}$ \\
\hline LCD & & & & & & & & \\
\hline & -1.039 & -2.846 & $-7.388 *$ & $-7.462 *$ & -1.034 & -2.781 & $-4.900 *$ & $-4.967 *$ \\
\hline LCL & -1.311 & -2.172 & $-5.992 *$ & $-6.035^{*}$ & -0.347 & -2.920 & $-3.896^{*}$ & $-3.872 *$ \\
\hline LID & -0.217 & -3.314 & $-8.013^{*}$ & $-7.992 *$ & -0.246 & -3.314 & $-7.900^{*}$ & $-7.855^{*}$ \\
\hline LIL & -0.712 & -2.099 & $-5.204^{*}$ & $-5.196^{*}$ & -0.938 & -2.648 & $-5.128^{*}$ & $-5.118^{*}$ \\
\hline LIPI & -2.752 & -3.065 & $-12.950 *$ & $-12.843^{*}$ & -1.971 & -2.012 & $-13.607 *$ & $-13.486^{*}$ \\
\hline ON & -0.103 & -1.897 & $-2.986^{*}$ & -3.227 & -0.355 & -2.395 & $-3.420 *$ & $-3.776^{*}$ \\
\hline LRER & -2.261 & -2.464 & $-5.749 *$ & $-5.711 *$ & -2.014 & -2.235 & $-4.572 *$ & $-4.589 *$ \\
\hline LP & -1.227 & -1.818 & $-5.656^{*}$ & $-5.757 *$ & -1.432 & -2.564 & $-5.520 *$ & $-5.656^{*}$ \\
\hline
\end{tabular}

\section{Cointegration results}

The study proceeds with the Johansen cointegration test to evaluate the existence of long-run relationship between the variables. Before running the cointegration test, it is necessary to identify the optimal lag length for the VAR model. To determine the lag length of the model, Akaike Information Criteria (AIC) is used. The minimum value of AIC is obtained with 5 lags for VAR:1-VAR:2 model and with 4 lags for VAR:3-VAR:4 model. Table 4 presents the cointegration test results. Trace test statistics suggest that there are at least two cointegrating relationships among the 
variables. Because cointegration relationship is identified between the variables, VEC model should be proposed as the appropriate estimation procedure.

Table 4. Result of the Johansen Cointegration Test

ON LCD LP LIPI LRER

\begin{tabular}{llll}
\hline \hline Hypothesized & Eigenvalue & $\begin{array}{l}\text { Trace } \\
\text { Statistic }\end{array}$ & Critical Value \\
\hline None * & 0.815971 & 175.1066 & 69.81889 \\
At most 1 * & 0.552178 & 90.47341 & 47.85613 \\
At most 2 $*$ & 0.473568 & 50.30541 & 29.79707 \\
At most $3 *$ & 0.277267 & 18.22378 & 15.49471 \\
At most 4 & 0.03898 & 1.987995 & 3.841466 \\
\hline ON LCL LP LIPI LRER & & \\
Hypothesized & Eigenvalue & Statistic & Critical Value \\
\hline None * & 0.694599 & 148.2111 & 69.81889 \\
At most 1 * & 0.524844 & 88.90467 & 47.85613 \\
At most 2 $*$ & 0.438419 & 51.69908 & 29.79707 \\
At most 3 $*$ & 0.349855 & 22.8491 & 15.49471 \\
At most 4 & 0.026076 & 1.321087 & 3.841466 \\
\hline ON LID LP LIPI LRER & & \\
Hypothesized & Eigenvalue & Statistic & Critical Value \\
\hline None * & 0.574904 & 107.6973 & 69.81889 \\
At most 1 * & 0.501456 & 64.0698 & 47.85613 \\
At most 2 & 0.319787 & 28.57052 & 29.79707 \\
At most 3 & 0.101329 & 8.917734 & 15.49471 \\
At most 4 & 0.065758 & 3.469004 & 3.841466 \\
\hline ON LIL LP LIPI LRER & & \\
Hypothesized & Eigenvalue & Statistic & Critical Value \\
\hline None * & 0.580045 & 106.3582 & 69.81889 \\
At most 1 * & 0.501213 & 62.11015 & 47.85613 \\
At most 2 & 0.304676 & 26.63572 & 29.79707 \\
At most 3 & 0.116688 & 8.103502 & 15.49471 \\
At most 4 & 0.034216 & 1.775589 & 3.841466 \\
\hline \hline
\end{tabular}

Notes: $*$ denotes rejection of the hypothesis at the 0.05 level

Impulse Response Function

The impulse responses are used to investigate the dynamic effects of interest rate shocks on the balance sheet items of the conventional and participation banks. Fig. 1 shows impulse-response functions based on VEC analysis in respect to loans and deposits for both conventional and Islamic banks. 

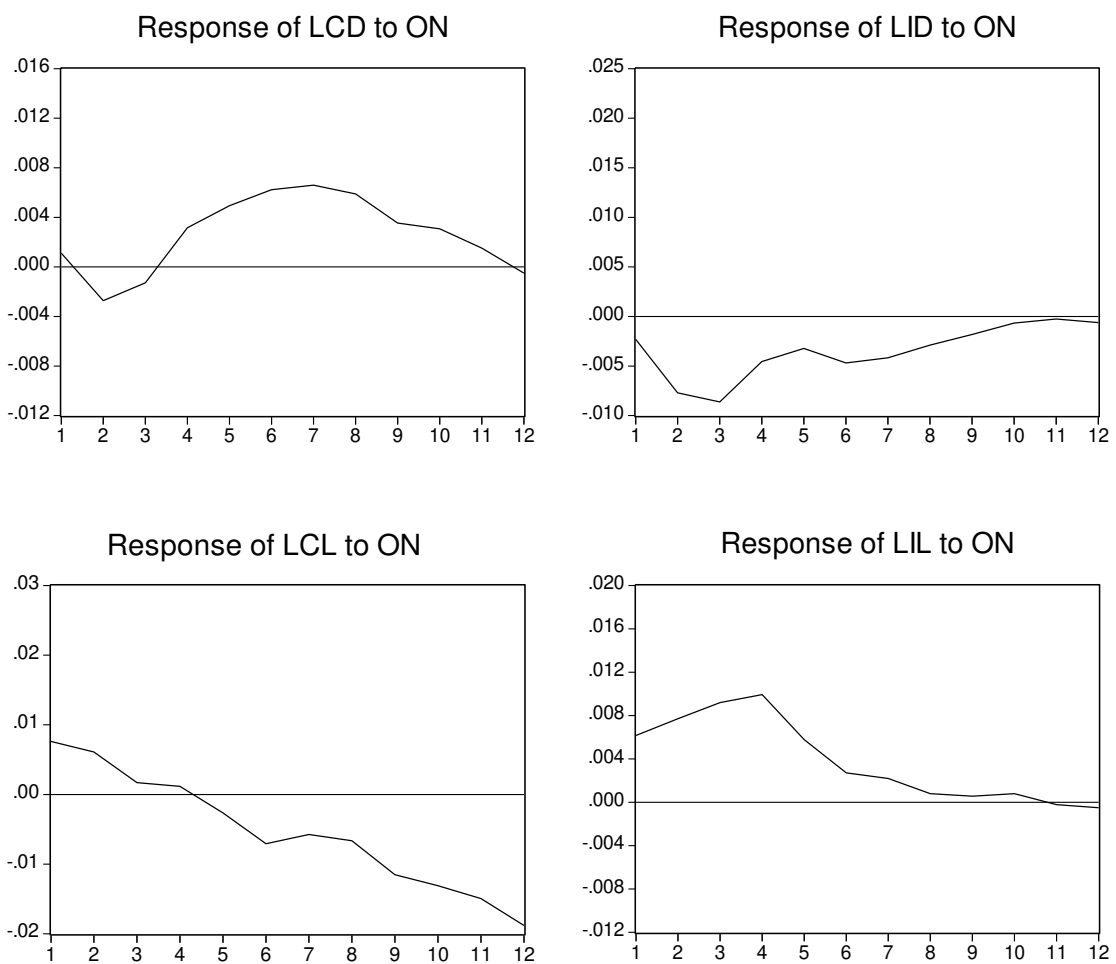

Fig. 1. Impulse-Response Function of deposits and loans

While the conventional bank deposit responds negatively to a positive shock in the interest rates through 4 months, the response turns into positive. The Islamic bank deposits, on the other hand, give a negative response to the interest rates. The initial level is viewed at the month 11 .

The response by the conventional bank loans to a shock in the interest rates is positive at the beginning whereas it gradually turns into negative after 4 months. The response of Islamic bank loans to interest rate shock, however, is positive.

The response of the deposits and the loans to the interest rates is consistent with the findings presented in a number of previous studies. The results as observed in the responses are almost identical to the findings by Kassim at al. (2009), Haron and Ahmad (2000), Kasri and Kassim (2009), Sukmana and Kassim (2010), Zaionol and Kassim (2010). An increase in the interest rates also increases the deposits held at the conventional banks whereas it negatively affects the Islamic bank deposits. The response of the loans is similar to the findings offered by Rosly (1999). While the conventional bank loans are negatively affected by the interest rates, the Islamic bank loans feature a positive response. This reveals that the Islamic banks in Turkey are visibly affected by the changes in interest rates. 
Variance Decomposition Analysis

Table 5. Result of Variance Decompositions of deposits

Variance Decomposition of $L C D$ :

\begin{tabular}{|c|c|c|c|c|c|c|}
\hline Period & S.E. & $O N$ & $L C D$ & $L P$ & LIPI & LRER \\
\hline 1 & 0.01 & 0.89 & 99.11 & 0.00 & 0.00 & 0.00 \\
\hline 2 & 0.02 & 2.85 & 86.46 & 9.13 & 0.13 & 1.43 \\
\hline 3 & 0.02 & 2.10 & 71.07 & 21.25 & 0.11 & 5.47 \\
\hline 4 & 0.03 & 2.62 & 64.53 & 23.89 & 1.39 & 7.58 \\
\hline 5 & 0.03 & 4.59 & 58.47 & 21.67 & 2.57 & 12.70 \\
\hline 6 & 0.03 & 7.63 & 53.95 & 20.67 & 2.91 & 14.85 \\
\hline 7 & 0.03 & 10.39 & 52.59 & 18.53 & 5.11 & 13.38 \\
\hline 8 & 0.04 & 12.21 & 52.42 & 17.19 & 5.34 & 12.83 \\
\hline 9 & 0.04 & 12.57 & 52.58 & 16.80 & 5.11 & 12.93 \\
\hline 10 & 0.04 & 12.43 & 53.31 & 16.32 & 5.11 & 12.83 \\
\hline 11 & 0.04 & 11.93 & 53.55 & 15.72 & 4.87 & 13.93 \\
\hline 12 & 0.04 & 11.44 & 53.11 & 15.72 & 4.78 & 14.95 \\
\hline \multicolumn{7}{|c|}{ Variance Decomposition of $L I D:$} \\
\hline Period & S.E. & $O N$ & $L I D$ & $L P$ & LIPI & $L R E R$ \\
\hline 1 & 0.02 & 1.08 & 98.92 & 0.00 & 0.00 & 0.00 \\
\hline 2 & 0.03 & 7.31 & 92.13 & 0.07 & 0.23 & 0.26 \\
\hline 3 & 0.03 & 11.41 & 84.38 & 2.30 & 1.14 & 0.78 \\
\hline 4 & 0.04 & 10.68 & 82.81 & 2.73 & 1.01 & 2.77 \\
\hline 5 & 0.04 & 10.37 & 79.84 & 2.53 & 1.31 & 5.96 \\
\hline 6 & 0.04 & 10.94 & 78.93 & 2.36 & 1.46 & 6.30 \\
\hline 7 & 0.04 & 11.21 & 78.58 & 2.48 & 1.39 & 6.35 \\
\hline 8 & 0.04 & 11.17 & 77.26 & 2.93 & 1.76 & 6.88 \\
\hline 9 & 0.04 & 11.05 & 75.68 & 3.85 & 2.46 & 6.97 \\
\hline 10 & 0.05 & 10.69 & 73.50 & 5.43 & 3.23 & 7.14 \\
\hline 11 & 0.05 & 10.19 & 71.10 & 7.23 & 4.18 & 7.31 \\
\hline 12 & 0.05 & 9.83 & 69.28 & 8.80 & 4.95 & 7.14 \\
\hline
\end{tabular}

VDC is a technique employed to identify the source of the change in the variables. A review of the tables below on VDC reveals that the interest rates are strong enough to explain both the conventional and Islamic bank deposits. However, the ability of the interest rates to explain the changes in the loans varies between the conventional and Islamic banks. The interest rates appear to be stronger to explain the change in the conventional bank loans. Therefore, for Islamic banks, the deposits are more affected by the interest rates than the loans. 
Table 6. Result of Variance Decompositions of loans

\begin{tabular}{lllllll}
\hline \multicolumn{7}{l}{ Variance Decomposition of $\boldsymbol{L C L}$ : } \\
\hline \hline Period & S.E. & ON & LCL & LP & LIPI & LRER \\
\hline 1 & 0.01 & 30.30 & 69.70 & 0.00 & 0.00 & 0.00 \\
2 & 0.02 & 21.90 & 65.22 & 0.71 & 2.07 & 10.10 \\
3 & 0.03 & 11.81 & 59.97 & 1.30 & 7.73 & 19.20 \\
4 & 0.04 & 6.82 & 55.19 & 0.74 & 11.51 & 25.74 \\
5 & 0.05 & 4.97 & 44.36 & 0.63 & 21.10 & 28.93 \\
6 & 0.06 & 5.09 & 32.80 & 0.61 & 31.50 & 30.00 \\
7 & 0.06 & 4.68 & 25.66 & 1.36 & 36.68 & 31.61 \\
8 & 0.07 & 4.51 & 20.05 & 1.49 & 42.74 & 31.22 \\
9 & 0.08 & 5.63 & 16.06 & 1.20 & 46.81 & 30.29 \\
10 & 0.09 & 6.97 & 13.54 & 1.02 & 48.40 & 30.08 \\
11 & 0.09 & 8.43 & 11.67 & 0.91 & 49.76 & 29.24 \\
12 & 0.10 & 10.60 & 10.56 & 0.95 & 49.48 & 28.41 \\
\hline Variance Decomposition of $\boldsymbol{L I L :}$ & & & \\
Period & S.E. & ON & LIL & LP & LIPI & LRER \\
\hline 1 & 0.01 & 18.99 & 81.01 & 0.00 & 0.00 & 0.00 \\
2 & 0.03 & 14.16 & 76.75 & 0.37 & 0.42 & 8.30 \\
3 & 0.04 & 14.69 & 61.43 & 2.17 & 4.78 & 16.93 \\
4 & 0.04 & 14.74 & 53.85 & 2.51 & 7.11 & 21.79 \\
5 & 0.05 & 11.80 & 48.42 & 1.80 & 13.00 & 24.98 \\
6 & 0.06 & 9.79 & 43.72 & 1.46 & 21.59 & 23.44 \\
7 & 0.06 & 8.46 & 40.81 & 1.33 & 27.94 & 21.46 \\
8 & 0.07 & 7.38 & 38.98 & 1.30 & 31.97 & 20.37 \\
9 & 0.07 & 6.65 & 38.42 & 1.24 & 34.50 & 19.18 \\
10 & 0.07 & 6.09 & 39.01 & 1.72 & 35.14 & 18.04 \\
11 & 0.08 & 5.57 & 39.49 & 2.62 & 35.12 & 17.20 \\
12 & 0.08 & 5.16 & 39.91 & 3.96 & 34.43 & 16.54 \\
\hline \hline
\end{tabular}

\section{Conclusion}

In parallel to the overall trend in global financial markets, Islamic banks are expanding their share in Turkish economy. Analyzing whether these banks that appear to be on rise are influenced by the changes in interest rates is crucial to identify their impact upon financial stability, monetary policy and risk management in banking. While it is theoretically expected that they are not affected by interest rates because they are carrying out interest-free banking activities, findings in a number of studies suggest that this is not the case.

This study analyzes the response of the deposits and loans held at conventional and Islamic banks to interest rates by utilization of monthly data for the period between 2005:12 and 2009:07 based on VAR methodology. The findings show that any change in the interest rates affects not only the deposits and loans of conventional banks but also such instruments of Islamic banks. This is fairly consistent with the findings publicized by Rosly (1999), Kassim et al. (2009), Haron and Ahmad (2000) 
Kasri and Kassim (2009), Sukmana and Kassim (2010), Zaionol and Kassim(2010). This at least partly invalidates the assumption and argument that the Islamic banks are more stable compared to the conventional banks just because they are performing interest-free banking and that they make positive contribution to the attainment of financial stability. The susceptibility of the Islamic banks to interest rates should be taken into account for a successful design of monetary policies. This is also importantly relevant in terms of risk management at these institutions and conventional banks as well. Unlike theoretical expectations, Islamic banks are influenced by interest rates, a fact suggesting that they are facing a serious interest rate risk.

\section{References}

Al-Jarhi, M. A. (2009) Islamic finance an efficient \& equitable option, The. Islamic Research and Training Institute, Islamic Development Bank, Available at http://www.iefpedia.com/english/wp-content/uploads/2009/11/

ISLAMICFINANCE-AN-EFFICIENT-EQUITABLE-OPTION.pdf

Arslan, B. G. and Ergeç E. H. (2010) The efficiency of participation and conventional banks in Turkey: using data envelopment analysis IRJFE, 57, 156-168.

Asteriou, D. and Hall, S. G. (2007) Applied Econometrics: A Modern Approach, Revised edn., Palgrave Macmillan, New York.

Awan, A. G. (2009) Comparision of Islamic and conventional banking in Pakistan, in Proceedings $2^{\text {nd }} C B R C$, Lahore, Pakistan.

Bacha, O. I. (2004) Dual banking systems and. interest rate risk for Islamic. banks, MPRA Paper No. 12763.

Chapra, U. M. (1996). Monetary policy in an Islamic economy in Money and Banking in Islam, A. Iqbal and Khan (ed.), International Centre for Research in Islamic Economics and Islamabad: Institute of Policy Studies, Jeddah, pp.27-68.

Chong, B. S. and Liu, M.-H. (2009) Islamic banking: interest-free or interest-based?, Pacific-Basin Finance Journal 17, 125-144. 
Darrat, A. F. (1988) The Islamic interest free banking system: some empirical evidences, Applied Economics. 20, 417-425.

Darrat, A. F. (2002) The relative efficiency of interest-free monetary system: some empirical evidence" The Quarterly Review of Economics and Finance, 42, 747-764.

Enders, W. (2004) Applied Econometric Time Series, 2nd edn, John Wiley\&Sons Inc.

Erol, C. and El-Bdour, R. (1989) Attitudes, behaviour, and patronage factors of bank customers towards Islamic banks, International Journal of Bank Marketing, 7, 31-37.

Errico, L. and Farahbaksh, M. (1998) Islamic banking: issues in prudential regulations and supervision IMF Working Paper, No. 30.

Gerrard, P. and Cunningham, J. B. (1997) Islamic banking: a study in Singapore, International Journal of Bank Marketing, 15, 204-216.

Griffiths, W. E., Hill, R. C. and Lim, G. C. (2008), Using EViews for Principles of Econometrics, 3rd edn, John Wiley\&Sons Inc.

Haron, S., Ahmad N., Planisek S.L. (1994) Bank patronage factors of Muslim and non-Muslim customers, International Journal of Bank Marketing, 12, 32-40.

Haron, S. and Shanmugam, B. (1997) Islamic Banking. System, Concepts and Applications, Pelanduk Publications. Singapore.

Haron, S. and Ahmad, N. (2000) The effects of conventional interest rates and rate of profits on funds deposited with Islamic banking system in Malaysia International Journal of Islamic Financial Services, 1, 1-7.

How, J. C,, Karim, M. A. and Verhoeven, P. (2005). Islamic financing and bank risk: the case of Malaysia. Thunderbird International Business Review, 47, 75-94. 
Kaleem, A. and Isa, M. M. (2006) Islamic banking and money demand function in Malaysia: an econometric analysis, Pakistan Economic and Social Review, 44, $277-$ 290.

Kasri, R. A. and Kassim, S. Hj. (2009) Empirical determinants of saving in the Islamic banks: evidence from Indonesia, Journal of King Abdulaziz University: Islamic Economics, 22, 181-201.

Kassim, S., Majid, M. A. and Yusof, R. M. (2009) Impact of monetary policy shocks on conventional and Islamic banks in a dual banking system: evidence from Malaysia, Journal of Economic Cooperation and Development, 30, 41-58.

Khan, M. S. and Mirakhor, A. (1989) The financial system and monetary policy in an Islamic economy, Journal of. King Abdulaziz University: Islamic Economics, 1, 3957.

Khan, M. S. and Mirakhor, A. (1990) Islamic banking: experiences in The Islamic Republic of Iran and in Pakistan, Economic Development and Cultural Change, 38, 353-375.

Kia, A. (2002) Interest-free and interest-bearing money demand: policy invariance and stability, Working Paper. Department of Economics, Emory University.

Kia, A. and Darrat, A. F. (2007) Modeling money demand under the profit- sharing banking scheme: evidence on policy invariance and long-run stability, Global Finance Journal, 18, 104-123.

Metawa, S.A. and Almossawi, M. (1998) Banking behavior of Islamic bank customers: perspectives and implications, International Journal of Bank Marketing, 16, 299-313.

Naser, K., Jamal, A. and Al-Khatib, K. (1999) Islamic banking: a study of customer satisfaction and preferences in Jordan, International Journal of Bank Marketing, 17 135-151. 
Nienhaus, V. (1983) Profitability of Islamic PLS banks competing with interest banks: problems and prospects, Journal of Research in Islamic Economics, 1, 31-39.

Okumuş, Ş. H. (2005) Interest-free banking in Turkey: a study of customer satisfaction and bank selection criteria, Journal of Economic Cooperation, 26, 51-86.

Participation Banks (2009). Publication of The Participation Banks Association of Turkey.

Rosly, S. (1999) Al-bay bithaman ajil financing: impacts on Islamic banking performance, Thunderbird International Business Review, 41, 461-480.

Said, F. and Ismail, A. G. (2008) Monetary policy, capital requirement and lending behaviour of Islamic banking in Malaysia, Journal of Economic Cooperation, 29, 122.

Sims, C. (1980) Macroeconomics and Reality, Econometrica, 48, 1-48.

Sukmana, R. and Kassim, S. H. (2010). Roles of the Islamic banks in the monetary transmission process in Malaysia, International Journal of Islamic and Middle Eastern Finance and Management, 3, 7-19.

Uzair, M. (1978) Central banking operations in an interest-free banking system, in Monetary and Fiscal Economics of Islam, Mohammad Ariff (ed.): International Centre for Research in Islamic Economics, Jeddah, pp. 211-235.

Van Schaik, D. (2001) Islamic banking, The Arab Bank Review, 3, 45-52.

Yudistira, D. (2004) Efficiency in Islamic banking: an empirical analysis of eighteen banks, Islamic Economic Studies, 12, 1-9.

Zaher, T. S. and Hassan, M. K. (2001) A comparative literature survey of Islamic finance and banking, Financial Markets, Institutions \& Instruments 10, 155-199. 
Zainol, Z. and Kassim S. H. (2010) An analysis of Islamic banks' exposure to rate of return risk, Journal of Economic Cooperation and Development, 31, 59-84.

Zangeneh, H. and Salam, A. (1993). Central banking in an interest free banking system, Journal of. King Abdulaziz University: Islamic Economics, 5, 25-36.

Zarqa, M. A. (1983) Stability in an interest-free Islamic economy: a note, Pakistan Journal of Applied Economics, 11, 181-188.

Zuberi, H. A. (1992) Interest free banking and economic stability, The Pakistan Development Review, 31, 1077-1087. 